\title{
Effect of kweni mango juice addition and percentage of carboxymethyl cellulose (CMC) on the physicochemical characteristics of watermelon albedo fruitghurt
}

\author{
Putri Tasya Nurhaliza ${ }^{1,}$ Linda Masniary Lubis ${ }^{1, *}$, and Zulkifli Lubis ${ }^{1}$ \\ ${ }^{1}$ Department of Food Science and Technology, Faculty of Agriculture, Universitas Sumatera Utara, \\ 20155,Medan, Indonesia.
}

\begin{abstract}
This research was conducted to determine the effect of kweni mango juice addition and percentage of Carboxymethyl Cellulose (CMC) on the physicochemical characteristics of watermelon albedo fruitghurt. The research used completely randomized design with two factors, i.e the addition of kweni mango juice $(12.5 \%, 15.0 \%, 17.5 \%)$ and percentage of Carboxymethyl Cellulose (CMC) $(0.3 \%, 0.5 \%, 0.7 \%)$. The results showed that kweni mango juice addition and percentage of Carboxymethyl Cellulose (CMC) had highly significant effect on ash content, vitamin $\mathrm{C}$ content, total lactic acid bacteria, and viscosity. The addition of kweni mango of $17.5 \%$ and $0.7 \%$ of Carboxymethyl Cellulose was the best treatment, based on the parameters of ash content, vitamin C content, total lactic acid bacteria, and viscosity. The antioxidant activity of fruitghurt with the best physicochemical characteristics was analyzed. The results showed that it was $75.15 \mu \mathrm{g} / \mathrm{mL}$.
\end{abstract}

\section{Introduction}

The development of fermented products, which are functional foods, continues to increase. One of the products is yoghurt, i.e., derived from fermented milk, and it has a texture like ice cream and tastes slightly sour [1]. Currently, yoghurt is not only made from fresh milk or skim milk, but can also be made with other raw materials. Like fruitghurt made from fruit juice. Fruitghurt is a fermented product of various fruit juices, including dragon fruit, melon, grapes, bananas, papaya, mango, blueberries, and others [2]. Even now, the fruit was constantly modified to get better characteristics and nutritional effects. One modification of fruitghurt is the use of raw materials from fruit waste, such as fruit peels. In general, watermelons are only consumed on the flesh that is strikingly colored, such as red and yellow. There are parts of watermelon that are less attractive to the public for consumption and are usually thrown away immediately, so that it becomes unutilized waste, namely albedo. According to [3], albedo is the thickest part of the watermelon skin, white in color, and contains nutrients for health, such as improving the blood circulation

*E-mail : $\underline{\text { linda3@usu.ac.id }}$ 
system [4]. The waste generated from watermelon is relatively high, around $30 \%$, so it needs to be appropriately properly handled in order not to pollute the environment.

Kweni mango is a fruit that has a distinctive flavor. Based on [5], $100 \mathrm{~g}$ of kweni mango contained $80 \%$ water, $15-20 \%$ sugar, fiber, and various vitamins, including vitamin $\mathrm{A}, \mathrm{B}_{1}$, $\mathrm{B}_{2}$, and a high vitamin $\mathrm{C}$ content of around 3-80mg. Therefore, the addition of kweni mango juice can increase the aroma, taste, as a natural colorant, and nutritional value of the fruitghurt. Stabilizers are needed to maintain the stability of the emulsion system so that syneresis does not occur in fruitghurt. Carboxymethyl Cellulose (CMC) is one of the stabilizers that can be used in the manufacture of fruitghurt. It is very easy to find in various places with relatively low prices and has the characteristics of being odourless, stable at $\mathrm{pH}$ 3-7, and does not react with organic compounds.

Therefore, research is needed to maximize the utilization of processed fruit-based waste into modern functional food products, to increase the added value and marketability of fruit, to produce a probiotic drink product in the form of fruitghurt, which is healthy and preferred for all ages, to determine the effect of kweni mango juice addition and percentage of Carboxymethyl Cellulose (CMC) on the physicochemical characteristics of watermelon albedo fruitghurt, and to obtain a formula with the best quality.

\section{Material and methods}

The materials used were watermelon albedo, kweni mango, full cream milk powder, Carboxymethyl Cellulose, and plain commercial yoghurt. It was obtained from the traditional market Setiabudi Street, Medan, North Sumatra. The reagents were ascorbic acid, MRSA (de Man, Rogosa, and Sharpe Agar), 2.6-dichlorophenol indophenols, ethanol, and DPPH (2.2-diphenyl-1-picrylhydrazil). This research was conducted at the Laboratory of Food Science and Technology and Central Laboratory Faculty Agriculture, Universitas Sumatera Utara, Medan.

\subsection{Research methodology}

Watermelon albedo juice was mixed with full cream milk powder as much as $9 \%$ of the blanched watermelon albedo juice weight. Watermelon albedo juice weight was $250 \mathrm{~g}$. Then, kweni mango juice was added as much as $12.5 \%, 15.0 \%$, and $17.5 \%$ and the addition of Carboxymethyl Cellulose (CMC) with percentages of $0.3 \%, 0.5 \%$, and $0.7 \%$. The materials were heated at $75^{\circ} \mathrm{C}$ for 10 minutes, cooled to $40^{\circ} \mathrm{C}$, and $10 \%$ starter was added. After that, the mix was stirred gently until evenly mixed. The fruitghurt was incubated at $40^{\circ} \mathrm{C}$ for 6 hours. After that, the fruitghurt was stored in the refrigerator for 10 hours to produce a ready-to-serve watermelon albedo fruitghurt. The evaluation of fruitghurt was carried out by analyzing ash content, vitamin $\mathrm{C}$ content, total lactic acid, and viscosity. The antioxidant activity of fruitghurt with the best physicochemical characteristics was analyzed.

\subsection{Statistical analysis}

The Completely Randomized Experimental Design was used in the research with two factors. Each treatment was repeated three times to reduce experimental errors. Data were analyzed by ANOVA and Duncan's test with a significance level of $1 \%$ and $5 \%$. 


\subsection{Ash content determination}

Ash content was determined by burning all organic content at a high temperature of about $500-600^{\circ} \mathrm{C}$. It was incinerated until light gray ash or constant weight was obtained. Then, the result of the combustion products were weighed [6].

\subsection{Vitamin C content}

Vitamin C content was determined based on the reduction of 2.6-dichlorophenol indophenols dye. In estimation of ascorbic acid, the prepared sample was titrated against standard 2.6-dichlorophenol indophenols dye to a pink endpoint. The titer was then used to calculate the ascorbic acid in the sample [7]

$$
\begin{aligned}
& \text { Vitamin C content (mg/100 g sample) }=\frac{\text { c.ac } \times \text { d.f } \times 100}{\mathrm{w}} \\
& \qquad \begin{aligned}
\text { c.ac } & =\text { Concentration of ascorbic acid } \\
\text { d.f } & =\text { Dilution factor } \\
\text { w } & =\text { Initial weight }(\mathrm{gr})
\end{aligned}
\end{aligned}
$$

\subsection{Total lactic acid bacteria}

Amount of $5 \mathrm{~mL}$ of sample was added to the Erlenmeyer flask containing $45 \mathrm{~mL}$ of aquadest in order to obtain $10^{1}$ dilution. Then, $1 \mathrm{~mL}$ of diluted sample was then diluted into $9 \mathrm{~mL}$ of aquadest to achieve $10^{2}$ dilution. Sample from the previous dilution was diluted by using the same method until reaching $10^{9}$ of dilution. $1 \mathrm{~mL}$ of sample from $10^{7}$ to $10^{9}$ of dilution was then transferred to a petri dish, mixed with $15 \mathrm{~mL}$ of de Man, Rogosa and Sharpe Agar (MRSA) medium. Those Petri dishes were then incubated at $37^{\circ} \mathrm{C}$ for 48 hours. Lactic acid bacteria colonies grown on the medium were then counted using colony counted according to standard plate count (SPC) [8].

\subsection{Viscosity}

Viscosity was determined by measurement time in seconds of the terminal velocity of the falling ball in a viscous liquid. This time indicates the viscosity of the sample with Pa.s as the viscosity unit [9].

\subsection{Antioxidant activity}

The ethanol extract of fruitghurt was added to $1 \mathrm{~mL}$ DPPH for each concentration, then vortexed and incubated for 30 minutes at room temperature. The absorbance was measured at $517 \mathrm{~nm}[10]$.

$$
\% \text { Inhibition }=\frac{\mathrm{Ab}-\mathrm{As}}{\mathrm{Ab}}
$$

$\mathrm{Ab}=\mathrm{DPPH}$ absorbances

As $=$ Sample absorbances 


\section{Results and discussions}

\subsection{Physicochemical characteristics of watermelon albedo fruitghurt}

Physicochemical characteristics of watermelon albedo fruitghurt analyzed were ash content, vitamin $\mathrm{C}$ content, total lactic acid bacteria, and viscosity. The effect of kweni mango juice addition on the physicochemical characteristics of watermelon albedo fruitghurt were shown in Table 1.

Table 1. The effect of kweni mango juice addition on the physicochemical characteristics of watermelon albedo fruitghurt

\begin{tabular}{ccccc}
\hline $\begin{array}{c}\text { Kweni Mango } \\
\text { Juice }\end{array}$ & $\begin{array}{c}\text { Ash content } \\
(\%)\end{array}$ & $\begin{array}{c}\text { Vitamin C content } \\
(\mathrm{mg} / 100 \mathrm{~g} \text { sample })\end{array}$ & $\begin{array}{c}\text { Total Lactic Acid } \\
\text { Bacteria }(\mathrm{CFU} / \mathrm{mL})\end{array}$ & Viscosity (Pa.s) \\
\hline $12.5 \%$ & $0.81 \pm 0.02^{\mathrm{c}, \mathrm{C}}$ & $14.46 \pm 0.17^{\mathrm{c}, \mathrm{C}}$ & $1.52 \times 10^{9} \pm 0.14^{\mathrm{c}, \mathrm{C}}$ & $10.90 \pm 0.06^{\mathrm{c}, \mathrm{C}}$ \\
$15.0 \%$ & $0.95 \pm 0.06^{\mathrm{b}, \mathrm{B}}$ & $15.79 \pm 0,41^{\mathrm{b}, \mathrm{B}}$ & $1.60 \times 10^{9} \pm 0.09^{\mathrm{b}, \mathrm{B}}$ & $11.25 \pm 0.09^{\mathrm{b}, \mathrm{B}}$ \\
$17.5 \%$ & $1.15 \pm 0.06^{\mathrm{a}, \mathrm{A}}$ & $16.61 \pm 0.08^{\mathrm{a}, \mathrm{A}}$ & $1.73 \times 10^{9} \pm 0.04^{\mathrm{a}, \mathrm{A}}$ & $11.67 \pm 0.19^{\mathrm{a}, \mathrm{A}}$ \\
\hline
\end{tabular}

Description: different superscripts on the same column by upper case letter showed a highly significant difference $(\mathrm{p}<0.01)$, and small letter showed a significant difference $(\mathrm{P}<0.05)$.

The effect of Carboxymethyl Cellulose addition on the physicochemical characteristics of watermelon albedo fruitghurt is shown in Table 2.

Table 2. The effect of Carboxymethyl Cellulose addition on the physicochemical characteristics of watermelon albedo fruitghurt

\begin{tabular}{ccccc}
\hline CMC & Ash content $(\%)$ & $\begin{array}{c}\text { Vitamin C content } \\
(\mathrm{mg} / 100 \mathrm{~g} \text { sample })\end{array}$ & $\begin{array}{c}\text { Total Lactic Acid } \\
\text { Bacteria }(\mathrm{CFU} / \mathrm{mL})\end{array}$ & Viscosity (Pa.s) \\
\hline $0.3 \%$ & $0.94 \pm 0.13^{\mathrm{b}, \mathrm{B}}$ & $15.46 \pm 1.02^{\mathrm{b}, \mathrm{B}}$ & $1.71 \times 10^{9} \pm 0.06^{\mathrm{a}, \mathrm{A}}$ & $11.22 \pm 0.37^{\mathrm{b}, \mathrm{B}}$ \\
$0.5 \%$ & $0.99 \pm 0.20^{\mathrm{a}, \mathrm{A}}$ & $15.58 \pm 1.19^{\mathrm{b}, \mathrm{B}}$ & $1.63 \times 10^{9} \pm 0.09^{\mathrm{b}, \mathrm{B}}$ & $11.25 \pm 0.33^{\mathrm{b}, \mathrm{AB}}$ \\
$0.7 \%$ & $1.01 \pm 0.19^{\mathrm{a}, \mathrm{A}}$ & $15.84 \pm 1.08^{\mathrm{a}, \mathrm{A}}$ & $1.54 \times 10^{9} \pm 0.16^{\mathrm{c}, \mathrm{C}}$ & $11.37 \pm 0.46^{\mathrm{a}, \mathrm{A}}$ \\
\hline
\end{tabular}

Description: different superscripts on the same column by upper case letter showed a highly significant difference $(\mathrm{p}<0.01)$, and small letter showed a significant difference $(\mathrm{P}<0.05)$.

\subsubsection{Ash content.}

The ash contents of kweni mango juice addition and percentage of Carboxymethyl Cellulose of watermelon albedo fruitghurt were highly significant differences $(\mathrm{P}<0.01)$. Both factors had relatively high ash content. Based on [11], ash content represents the inorganic residue remaining after ignition and complete oxidation of organic matter in a food sample. Ash content represents the total mineral content in foods. According to [12], the ash content of kweni mango is $0.82 \%$, and Carboxymethyl Cellulose is classified as a macro mineral with $0.6 \%$. 


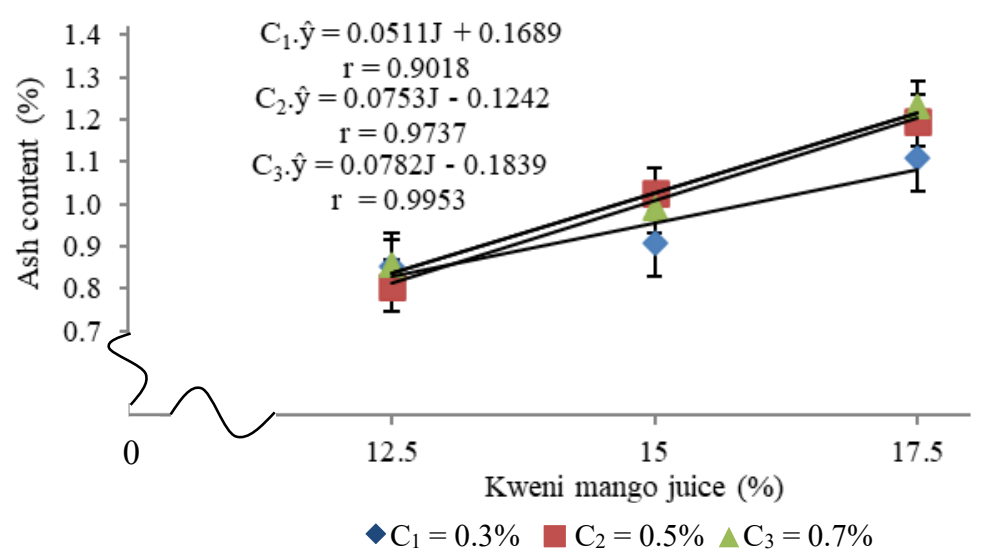

Fig 1. The relationship between kweni mango juice addition and percentage Carboxymethyl Cellulose on ash content of watermelon albedo fruitghurt

\subsubsection{Vitamin C content.}

The vitamin $C$ content of kweni mango juice addition and percentage of Carboxymethyl Cellulose of watermelon albedo fruitghurt were significantly different $(\mathrm{P}<0.01)$. Based on the analysis of raw materials, it shows that kweni mango juice has a fairly high vitamin $\mathrm{C}$ content of $16.87 \mathrm{mg} / 100 \mathrm{~g}$. According to [13], Carboxymethyl Cellulose can stabilize the ingredients and bind of water. Thus, damage vitamin $\mathrm{C}$ due to water solubilization can be prevented.

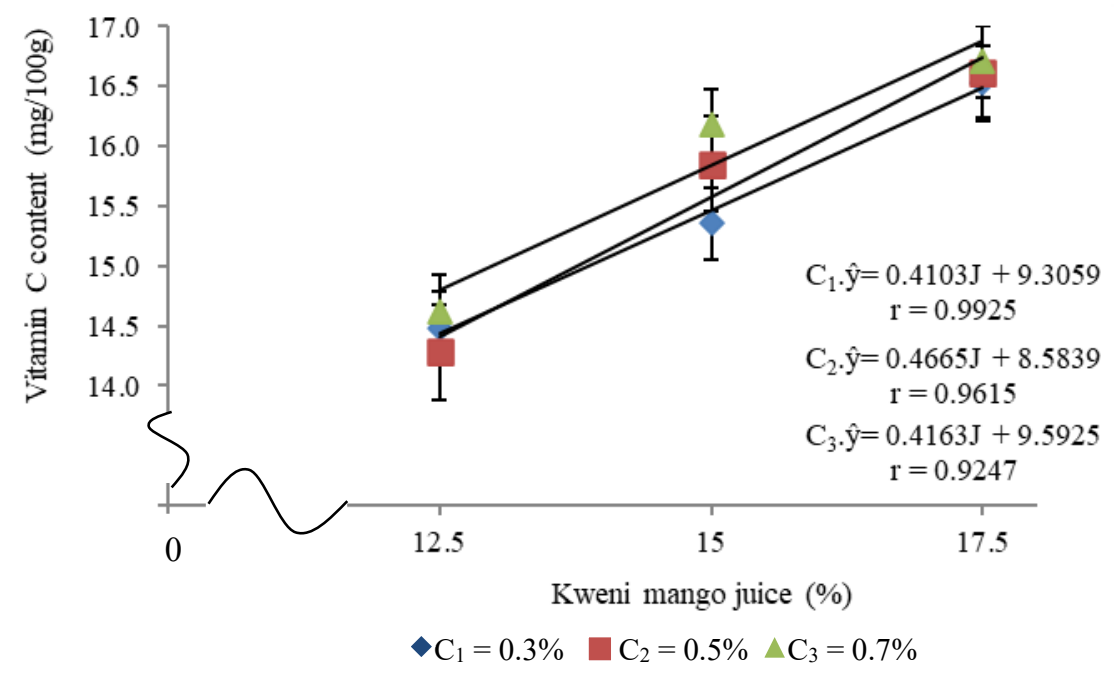

Fig 2. The relationship between kweni mango juice addition and percentage Carboxymethyl Cellulose on vitamin $\mathrm{C}$ content of watermelon albedo fruitghurt

\subsubsection{Total lactic acid bacteria.}

The total lactic acid bacteria of kweni mango juice addition and percentage of Carboxymethyl Cellulose of watermelon albedo fruitghurt were highly significant differences $(\mathrm{P}<0.01)$. The addition of kweni mango $17.5 \%$ and $0.3 \%$ of Carboxymethyl Cellulose can increase total lactic acid bacteria because kweni mango had the highest 
carbohydrate content, and Carboxymethyl Cellulose has the least ability to bind of water. According to [14], total lactic acid bacteria was influenced by carbohydrates and water as a medium for microbial growth.

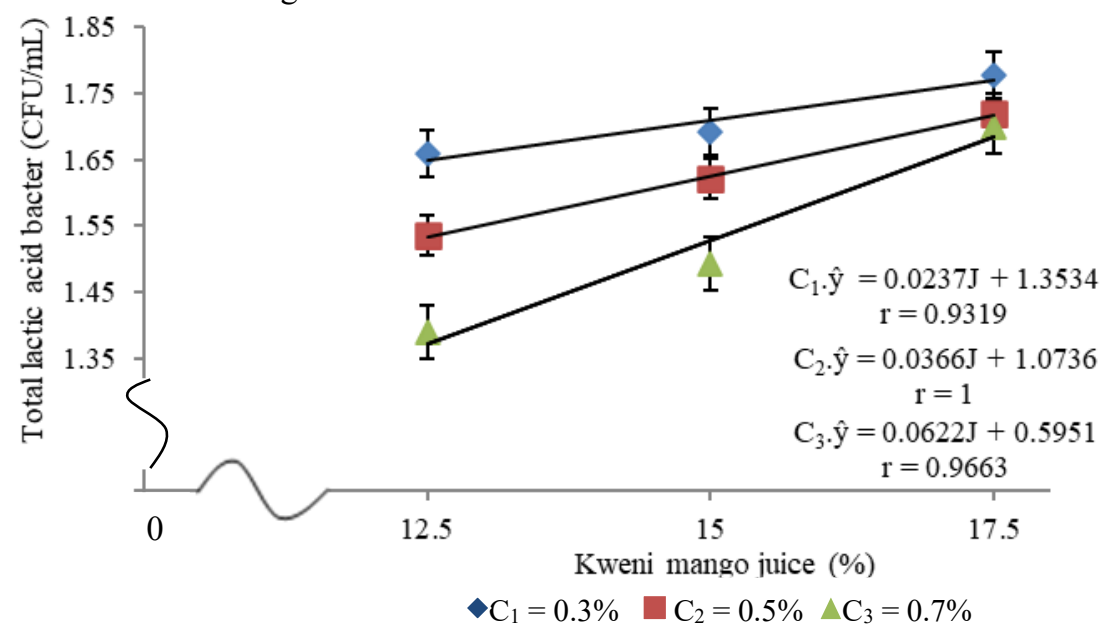

Fig 3. The relationship between kweni mango juice addition and percentage Carboxymethyl Cellulose on total lactic acid bacteria of watermelon albedo fruitghurt

\subsubsection{Viscosity.}

The viscosity of kweni mango juice addition and percentage of Carboxymethyl Cellulose of watermelon albedo fruitghurt were significantly different $(\mathrm{P}<0.01)$. Kweni mango juice is one of the fruits that contain pectin. According to [15], Carboxymethyl Cellulose was a hydrophilic stabilizer that binds water, and water molecules will be trapped in the formed gel texture. Consequently, the viscosity of watermelon albedo fruitghurt can increase.

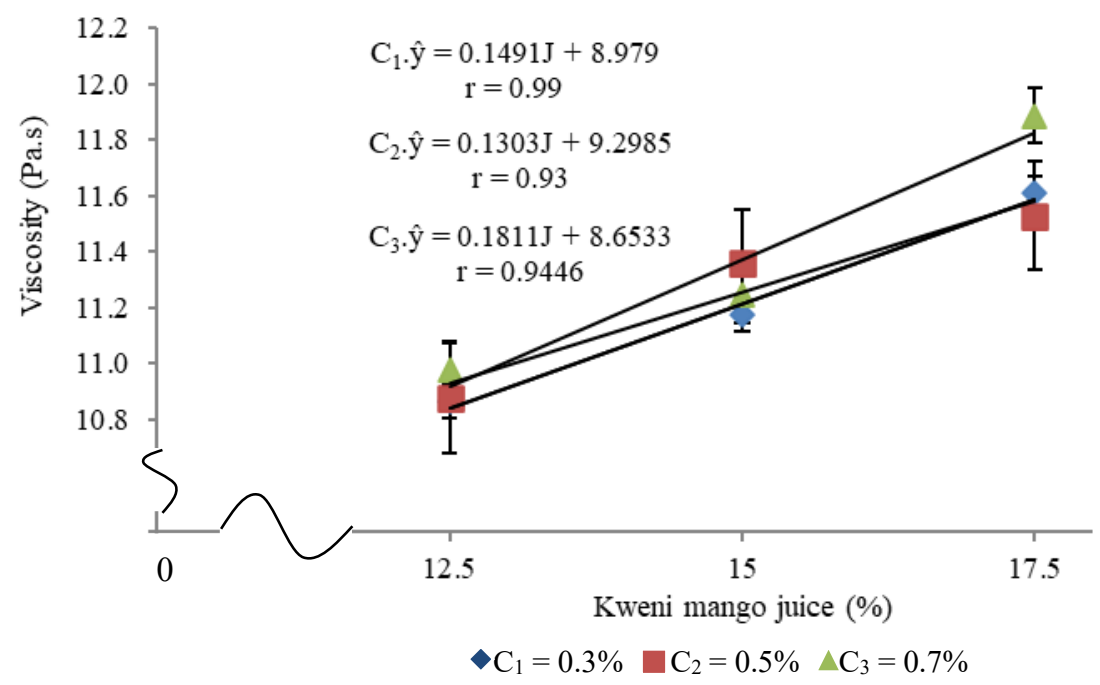

Fig 4. The relationship between kweni mango juice addition and percentage Carboxymethyl Cellulose on the viscosity of watermelon albedo fruitghurt 


\subsection{Antioxidant activity.}

The antioxidant activity of fruitghurt with the best physicochemical characteristics was analyzed. The results showed that it was $75.15 \mu \mathrm{g} / \mathrm{mL}$. Thus, watermelon albedo fruitghurt belongs to the active antioxidant category. According to [16], the active type of antioxidant activity has an $\mathrm{IC}_{50}$ value between $50-100 \mu \mathrm{g} / \mathrm{mL}$.

\section{Conclusion}

The research has shown that kweni mango juice addition and percentage of Carboxymethyl Cellulose could increased ash content, vitamin $\mathrm{C}$ content, total lactic acid, viscosity, and has provided significant difference in each parameter of physicochemical characteristics of watermelon albedo fruitghurt analysis. It could be concluded that watermelon albedo fruitghurt had potential value as a functional food.

\section{References}

1. A. Y. Tamime and R. K. Robinson. Yoghurt Science and Technology. (CRC Press, United States of America 2007).

2. A. N. Mawarni and N. H. Fithriyati. Effect of starter concentration on lactic acid levels in the making of fruitghurt from the skin of watermelon. National Seminar on Science and Technology, Jakarta (2015).

3. Yusni and S. Widodo, Journal of Synergy Multidisciplinary Science and Technology. 1(1), 309-315 (2018).

4. A. M. Rimando and P. M. Perkins-Veazie, Journal of Chromatography. 1078(1), $196-200$ (2005).

5. Pracaya. Planting mangoes. (Swadaya, Jakarta 2011).

6. The National Standardization Agency of Indonesia. SNI 01-3451-1994 (1994).

7. A. Apriyantono, D. Fardiaz, N. L. Puspitasari, Y. Sedarnawati, and S. Budianto. Instructions for Food Analysis Laboratory. (Inter University Center Bogor Agricultural University, Bogor 1989).

8. A. H. Septiani, Kusrahayu, and A. M. Legowo, Animal Agriculture Journal. 2(1), 1686-1691 (2013).

9. A. Budianto. Method of determining the viscosity coefficient of a liquid using linear regression Stokes law. National Seminar IV Human Resources for Nuclear Technology. 157-166 (2008).

10. L. F. Frindryani. Isolation and antioxidant activity of compounds in the ethanol extract of Temu Kunci (Boesenbergia pandurata) using the DPPH method. Thesis: Yogyakarta State University, Yogyakarta (2016).

11. F. G. Winarno. Food Chemistry and Nutrition. (Gramedia Pustaka Utama, Jakarta 2008).

12. S. S. Antarlina, Journal of the Germplasm Bulletin. 15(2), 80-90 (2009).

13. F. Putri, R. J. Nainggolan, L. N. Limbong, Journal of Agricultural and Food Engineering. 3(4), 465-470 (2015).

14. F. Ferdaus, M. O. Wijayanti, E. S. Retnonigtyas, and W. Irawati, Journal of Widya Technique. 7(1), 1-14 (2008).

15. Daniel, Z. Lubis, and E. Yusraini, Journal of Agricultural and Food Engineering. 5(1), 66-72 (2017).

16. Muharni, Elfita, and Amanda. The antioxidant activity of the compound (+) moreello flavone from the bark of the gamboges plant (Garcinia xanthocymus). 
Seminar Proceedings of the Faculty of Mathematics and Natural Sciences, University of Lampung (2013). 